\title{
Especial
}

\section{Can statins improve outcome in colorectal surgery? Part I}

\author{
Júlio César M. Santos JR ${ }^{1}$
}

${ }^{1}$ Full Professor, Sociedade Brasileira de Coloproctologia (TSBCP) - Guaratinguetá (SP), Brazil.

Santos JR JCM. Can statins improve outcome in colorectal surgery? Part I. J Coloproctol, 2012;32(3): 334-338.

\begin{abstract}
Statins are recommended for people who have high serum cholesterol, and this role of statins has been well documented. However, some activities of statins, independent of their lipid-lowering effect, in conditions such as systemic inflammatory response syndrome, nephropathy, and other anti-inflammatory activities that reduce proinflammatory cytokines, are called "pleiotropic" effects of statins. For this reason, many candidates for surgical treatment are users of statins. As a result, benefits are observed in these patients, such as minimized postoperative complications, especially in cardiac or coronary surgery. This study was designed with the purpose of determining the current status of the use of statins as an adjuvant in the prevention of postoperative complications in colorectal surgery. Ongoing studies and future researches will help clarify the potential impact of statins on the prophylaxis of postoperative complications.
\end{abstract}

Keywords: statins; postoperative complications; colorectal surgery.

RESUMO: As estatinas são drogas com o poder de inibir a hidroxi-metil-glutaril coenzima A redutase (HMG-CoA redutase), enzima que age na ativação da cadeia metabólica do colesterol. Portanto, sua principal ação, entre outros efeitos, é diminuir a concentração sérica total desse lipídeo. Por essa razão, muitas pessoas candidatas ao tratamento cirúrgico são pacientes usuários das estatinas. Seus outros efeitos, independente de sua capacidade para baixar os lipídeos circulantes, são denominados "efeitos pleiotrópicos" e estão, principalmente, relacionados à ação de bloqueio das atividades pró-inflamatórias, sobretudo minimizando, nos cardiopatas ou coronariopatas submetidos às operações cardíacas ou coronarianas, a prevalência da síndrome da reação inflamatória sistêmica, inclusive quando desencadeada por infecção. Estudos recentes têm sido elaborados para maiores conhecimentos dos mecanismos de ação das estatinas, especialmente em pacientes cardiopatas submetidos a tratamentos cirúrgicos não cardíacos ou em outros pacientes com o propósito de fazer a profilaxia das complicações pós-operatórias, inclusive as relacionadas diretamente com os agentes infecciosos. O presente manuscrito foi delineado com o objetivo de se conhecer a situação atual do uso das estatinas como adjuvante na prevenção das complicações pós-cirúrgicas em operações colorretais.

Palavras-chave: estatinas; complicações pós-operatórias; cirurgias colorretais.

\section{INTRODUCTION}

HMG-CoA (hydroxy-methyl-glutaryl-Coenzyme A or HMG-CoA reductase) - the enzyme that catalyzes the reduction reaction - is part of the metabolic pathway that produces cholesterol and targeted by several blocking substances when the purpose is to reduce the production of this lipid.

The inhibitors of HMG-CoA reductase are drugs known as statins, which belong to the group of drugs used in the prevention of cardiovascular dis- eases caused by elevated total circulating cholesterol. Statins are widely used, and most candidates for surgical treatments, including colorectal surgery, especially patients with neoplastic diseases, due to their age, are users of statins.

Statins reduce the serum levels of low-density lipoproteins (LDL) and triglycerides and promote increased levels of high-density lipoproteins (HDL) ${ }^{1}$. Plainly explained, increased LDL leads to more fatty deposits and formation of platelets in the endothelium of arteries, producing thicker walls and narrowed lu-

Study carried out at the Hospital e Maternidade Frei Galvão de Guaratinguetá - Guaratinguetá (SP), Brazil.

Financing source: none.

Conflict of interest: nothing to declare.

Submitted on: $02 / 27 / 2012$

Accepted on: 02/28/2012 
men of vessels (atherosclerosis) with functional involvement of several organs. Statins reduce LDL, as well as the size of platelets in coronary arteries ${ }^{2-4}$.

Several studies have been highlighted to show that statins reduce the incidence of coronary artery diseases and cerebrovascular lesions, and improve the survival rate of patients with coronary artery diseases $^{5-8}$; benefits can be obtained even in the beginning of the treatment ${ }^{3}$.

This study was designed with the purpose of determining the current status of the use of statins as an adjuvant in the prevention of postoperative complications in colorectal surgery.

\section{Other benefits of statins (pleiotropy)}

Statins also have an anti-inflammatory effect, particularly regarding the incidence of cardiovascular infection and complications during surgical procedures and they control the metabolic response to stress, facts that suggest the preventive use of statins in candidates for surgery ${ }^{9}$, and not only in patients to be submitted to cardiac surgeries due to several types of lesions, but also in cardiac patients undergoing non-cardiac operations. These conclusions resulted from the observation that the benefits provided by statins do not only depend on its LDL-lowering effect, but also on the impact of these drugs on organs, systems and morbid status, regardless of its original mechanism of action, which are properties called "pleotropic effects".

These effects, promoted by several mechanisms, suggest the extended therapeutic action of statins, including: the anti-inflammatory power, as they reduce the plasma concentration of cytokines - tumor necrosis factor-alpha (TNF- $\alpha$ ) and interleukins (IL-6) - and positively act in situations with significant elevation of C-reactive protein (CRP) $)^{1,3,9-20}$.

\section{Sepsis}

On the other hand, there are evidences ${ }^{21-24}$ and controversies $^{25-29}$ that require a better definition that statins, independent of their primary action, help reduce mortality in the treatment of sepsis ${ }^{21,25,30}$, supposedly for inhibiting the synthesis of products of the cholesterol metabolic pathway just before mevalonate is produced, preventing the production of substances such as isoprenoids and geranylgeranyl pyro- phosphate ${ }^{31}$. In addition, they modify the intercellular interaction and the chemotaxis of the immune system; have antioxidant properties, although reducing the levels of ubiquinone (CoQ10), an endogenous oxidant $^{32}$; act against apoptosis; inhibit the action of certain genes, changing the cellular activity; and participate, in other mechanisms, of the inflammatory response $^{30}$, facts that intensify their capability to control the systemic inflammatory response syndrome and protect cardiac patients from complications of noncardiac surgeries $\mathrm{s}^{33-35}$ or in similar situations triggered by the infection ${ }^{22-24,36,37}$. However, most studies testing the effect of statins in the treatment of severe diseases present methodological limitation and are retrospective studies ${ }^{30}$.

Almog et al. ${ }^{21}$, in a prospective study with the participation of several researchers, consecutively enrolled 361 patients admitted with presumed or documented acute bacterial infection. These patients presented high rates of severe sepsis and transference to the intensive care unit. Eighty-two patients (22.7\%), treated with statin before the admission, constituted a group that was compared to another group of 279 people that did not receive statin. The similar aspect of both groups was the severity of diseases that led to hospital admission. Acute sepsis affected $19 \%$ of the patients in the second group (without statin) and only $2.4 \%$ of the patients in the first group (treated with statin) $(\mathrm{p}<0.001)$. The statin group was associated with the relative risk of developing severe sepsis of 0.13 (95\% CI, 0.03 to 0.52 ) and reduced absolute risk of $16.6 \%$. The global admission rate at the intensive care unit was $10.2 \%$ (37/361): $12.2 \%$ in the non-statin group and $3.7 \%$ in the statin group $(\mathrm{p}=0.025)$, meaning that the treatment with statin may be associated with a reduced rate of severe sepsis and admission to the intensive care unit.

\section{Surgeries}

The systemic inflammatory response syndrome can affect 30 to $40 \%$ of the patients submitted to coronary artery bypass surgery ${ }^{38}$ or other types of cardiac or non-cardiac surgeries in patients with heart problems or coronary artery diseases; and these facts, based on the probable benefits of statins, encouraged the American Heart Association to highlight in 2007 the evidences that supported the use of statins during 
the surgeries to prevent cardiac complications resulting from non-cardiac surgeries ${ }^{39}$.

The incidence and increased risk of postoperative infectious or non-infectious complications depend on a relatively high variety of factors, especially in colorectal surgeries for the treatment of large bowel cancer ${ }^{40-42}$, whose discussion is not included in the scope of this study.

However, the purpose today is to know whether the current surgical treatment practices supported by technical, mechanical or other developments, considering the global support to health, and combined with improved skills of surgeons, and by scientific investigations on methods used during the surgery that recommend to discard unnecessary and harmful "traditional practices" 43 - such as preoperative mechanical preparation of the large bowel, use of nasogastric probe, cavity drainage, extended bed rest, gradual introduction of diet, among others ${ }^{44,45}$ - can, associated with a statin-like drug, promote improved results after colorectal surgeries, just as those that have been observed in cardiac surgeries ${ }^{46-48}$.

\section{Statin in colorectal surgeries}

Recently, Khan et al. ${ }^{49}$ and Singh et al. ${ }^{20}$, interested in reducing postoperative morbidity, studied the immediate effect of statin during colorectal surgeries. Among the first authors, the group of patients enrolled in the study had $21.7 \%$ of statin-treated patients - who were much older than the other patients (74.7 vs. 69.2 years old; $\mathrm{p}=0.022$ ), had more associated disorders and used more antidiabetic agents or other cardiovascular drugs. No difference was observed in relation to mortality between both groups or in the incidence of hospital infection or postoperative sepsis. However, regarding the aspect of being or not admitted to Intensive Care Unit (ICU), the statintreated patients were significantly less inclined to develop systemic inflammatory response syndrome or surgical wound infection or to ICU admission as a result of inflammatory or infectious sequelae. The second authors studied a group of 269 patients, 86 $(32 \%)$ of them received statin during the surgery and the others $(68 \%)$ did not. The statin-treated patients were older (72 vs. 69 years old; $\mathrm{p}=0.021)$, with predominance of male over female patients (53 vs. 40\%; $\mathrm{p}=0.049$ ), and included more patients in class III of American Society of Anesthesiology (ASA) classification ( 55 vs. $22 \%$; $<<0.001$ ), whose classes range from I to IV. No significant difference was observed in the total number of complications or in the hospital length-at-stay and both groups presented comparable functional recovery. However, they observed that statin-treated patients showed a significantly lower number of anastomotic dehiscence cases ( $1 \mathrm{vs}$. $7 \% ; \mathrm{p}=0.031)$. In addition, they concluded that the statin-treated group presented more deficient health and high surgical risk than the others, but obtained a similar global result to non-statin group, suggesting that this therapy produced a protective result.

Another relevant aspect refers to recent observations that highlight the relation between the local or systemic inflammation process and the pathogenesis of solid tumors ${ }^{50,51}$ in which pro-inflammatory macrophages, cytokines and chemotactic cytokines, acting as factors that predispose the subsequent progression, growth, invasion and metastasis of tumors, would determine the bad prognosis in the treatment of these patients $^{52}$. In this sense, Gunter et al..$^{53}$, in 2006, showed the relation of chronic inflammatory process, evidenced through a persistently elevated dose of CRP, with colorectal cancer. On the other hand, some genetic epidemiological studies showed that elevated CRP does not cause cancer, but it increased the risk of death caused by cancer ${ }^{54,55}$, suggesting that not only the intrinsic properties of tumors determine their behaviors. Therefore, for these reasons, the prevention of pro-inflammatory activities should be part of the adjuvant therapeutic arsenal in cancer treatment and in prophylaxis of general postoperative complications ${ }^{50-52}$.

The studies available are still not sufficient to ensure a better evaluation of the pleiotropic effects of statins and their probable benefits in colorectal surgeries, but the University of Auckland, New Zeland ${ }^{56}$, is interested in the topic and has assigned a group to start a multi-center cohort study to help clarify the impact of pleiotropic effects of statins on the prophylaxis of postoperative complications. 


\section{REFERENCES}

1. Maron DJ, Fazio S, Linton MF. Current perspectives on statins. Circulation 2000;101(2):207-13.

2. Von Birgelen C, Hartmann M, Mintz GS, Baumgart D, Schmermund A, Erbel R. Relation between progression and regression of atherosclerotic left main coronary artery disease and serum cholesterol levels as assessed with serial longterm ( $>$ or $=12$ months) follow-up intravascular ultrasound. Circulation 2003;108(22):2757-62.

3. Node K, Fujita M, Kitakaze M, Hori M, Liao JK. Short-term statin therapy improves cardiac function and symptoms in patients with idiopathic dilated cardiomyopathy. Circulation 2003;108(7):839-43.

4. Nissen SE, Tuzcu EM, Schoenhagen P, Brown BG, Ganz $\mathrm{P}$, Vogel RA, et al. Effect of intensive compared with moderate lipid-lowering therapy on progression of coronary atherosclerosis: a randomized controlled trial. JAMA 2004;291(9):1071-80.

5. Influence of pravastatin and plasma lipids on clinical events in the West of Scotland Coronary Prevention Study (WOSCOPS). Circulation 1998;97(15):1440-5.

6. Heart Protection Study Collaborative Group. MRC/ BHF Heart Protection Study of cholesterol lowering with simvastatin in 20,536 high-risk individuals: a randomised placebo-controlled trial. Lancet 2002;360(9326):7-22.

7. Horwich TB, MacLellan WR, Fonarow GC. Statin therapy is associated with improved survival in ischemic and nonischemic heart failure. J Am Coll Cardiol 2004;43(4):642-8.

8. Amarenco P, Goldstein LB, Szarek M, Sillesen H, Rudolph AE, Callahan A 3rd, et al. Effects of intense low-density lipoprotein cholesterol reduction in patients with stroke or transient ischemic attack: the Stroke Prevention by Aggressive Reduction in Cholesterol Levels (SPARCL) trial. Stroke 2007;38(12):3198-204.

9. Brookes ZL, McGown CC, Reilly CS. Statins for all: the new premed? Br J Anaesth 2009;103(1):99-107.

10. Faggiotto A, Paoletti R. Do pleiotropic effects of statins beyond lipid alterations exist in vivo? What are they and how do they differ between statins? Curr Atheroscler Rep 2000;2(1):20-5.

11. Davignon J, Mabile L. Mechanisms of action of statins and their pleiotropic effects. Ann Endocrinol 2001;62(1 Pt 2):101-12.

12. Gotto Jr AM Jr, Farmer JA. Pleiotropic effects of statins: do they matter? Curr Opin Lipidol 2001;12(4):391-4.

13. LaRosa JC. Pleiotropic effects of statins and their clinical significance. Am J Cardiol 2001;1;88(3):291-3.

14. Liao JK, Laufs U. Pleiotropic effects of statins. Annu Rev Pharmacol Toxicol 2005;45:89-118.

15. Crisby M. The role of pleiotropic effects of statins in dementia. Acta Neurol Scand Suppl 2006;185:115-8.

16. Almuti K, Rimawi R, Spevack D, Ostfeld RJ. Effects of statins beyond lipid lowering: potential for clinical benefits. Int J Cardiol 2006;109(1):7-15.
17. Poli A, Pujia A. Pleiotropic effects of statins and early benefit in the Prove it-TIMI-22 study. J Am Coll Cardiol 2006;48(4):852.

18. Ridker PM, Danielson E, Fonseca FA, Genest J, Gotto AM Jr, Kastelein JJ, et al. Rosuvastatin to prevent vascular events in men and women with elevated C-reactive protein. N Engl J Med 2008;359(21):2195-207.

19. Birnbaum Y, Ye Y. Pleiotropic effects of statins: the role of eicosanoid production. Curr Atheroscler Rep 2012 [Epub].

20. Singh PP, Srinivasa S, Bambarawana S, Lemanu DP, Kahokehr AA, Zargar-Shoshtari K, et al. Perioperative use of statins in elective colectomy. Dis Colon Rectum 2012;55(2):205-10.

21. Almog Y, Shefer A, Novack V, Maimon N, Barski L, Eizinger $\mathrm{M}$, et al. Prior statin therapy is associated with a decreased rate of severe sepsis. Circulation 2004;110(7):880-5.

22. Janda S, Young A, Fitzgerald JM, Etminan M, Swiston J. The effect of statins on mortality from severe infections and sepsis: a systematic review and meta-analysis. J Crit Care 2010;25(4):656.e7-22.

23. Kouroumichakis I, Papanas N, Proikaki S, Zarogoulidis $\mathrm{P}$, Maltezos E. Statins in prevention and treatment of severe sepsis and septic shock. Eur J Intern Med 2011;22(2):125-33.

24. Vandermeer ML, Thomas AR, Kamimoto L, Reingold A, Gershman K, Meek J, et al. Association between use of statins and mortality among patients hospitalized with laboratory-confirmed influenza virus infections: a multistate study. J Infect Dis 2012;205(1):13-9.

25. Gao F, Linhartova L, Johnston AM, Thickett DR. Statins and sepsis. Br J Anaesth 2008;100(3):288-98.

26. Yende S, Milbrandt EB, Kellum JA, Kong L, Delude RL, Weissfeld LA, et al. Understanding the potential role of statins in pneumonia and sepsis. Crit Care Med 2011;39(8):1871-8.

27. Woerndle RH, Maxwell DL. Statins and sepsis: good bullet, disappearing target. J Am Osteopath Assoc 2008;108(9):486-90.

28. van den Hoek HL, Bos WJ, de Boer A, van de Garde EM. Statins and prevention of infections: systematic review and meta-analysis of data from large randomised placebo controlled trials. BMJ 2011;343:d7281.

29. Rodríguez de Antonio LA, Martínez-Sánchez P, MartínezMartínez MM, Cazorla-García R, Sanz-Gallego I, Fuentes $\mathrm{B}$, et al. Previous statins treatment and risk of post-stroke infections. Neurologia 2011;26(3):150-6.

30. Falagas ME, Makris GC, Matthaiou DK, Rafailidis PI. Statins for infection and sepsis: a systematic review of the clinical evidence. J Antimicrob Chemother 2008;61(4):774-85.

31. Goldstein JL, Brown MS. Regulation of the mevalonate pathway. Nature 1990;343(6257):425-30.

32. Rundek T, Naini A, Sacco R, Coates K, DiMauro S. Atorvastatin decreases the coenzyme Q10 level in the blood of patients at risk for cardiovascular disease and stroke. Arch Neurol 2004;61(6):889-92. 
33. O’Neil-Callahan K, Katsimaglis G, Tepper MR, Ryan J, Mosby C, Ioannidis JP, et al. Statins decrease perioperative cardiac complications in patients undergoing noncardiac vascular surgery: the Statins for Risk Reduction in Surgery (StaRRS) study. J Am Coll Cardiol 2005;45(3):336-42.

34. Ray KK, Cannon CP. The potential relevance of the multiple lipid-independent (pleiotropic) effects of statins in the management of acute coronary syndromes. J Am Coll Cardiol 2005;46(8):1425-33.

35. Robinson JG, Smith B, Maheshwari N, Schrott H. Pleiotropic effects of statins: benefit beyond cholesterol reduction? A meta-regression analysis. J Am Coll Cardiol 2005;46(10):1855-62.

36. Tleyjeh IM, Kashour T, Hakim FA, Zimmerman VA, Erwin PJ, Sutton AJ, et al. Statins for the prevention and treatment of infections: a systematic review and meta-analysis. Arch Intern Med 2009;169(18):1658-67.

37. O’Neal HR Jr, Koyama T, Koehler EA, Siew E, Curtis BR, Fremont RD, et al. Prehospital statin and aspirin use and the prevalence of severe sepsis and acute lung injury/acute respiratory distress syndrome. Crit Care Med 2011;39(6):1343-50.

38. Menasché P. The inflammatory response to cardiopulmonary bypass and its impact on postoperative myocardial function. Curr Opin Cardiol 1995;10(6):597-604.

39. Fleisher LA, Beckman JA, Brown KA, Calkins H, Chaikof E, Fleischmann KE, et al. ACC/AHA 2007 guidelines on perioperative cardiovascular evaluation and care for noncardiac surgery: executive summary: a report of the American College of Cardiology/American Heart Association Task Force on Practice Guidelines (Writing Committee to Revise the 2002 Guidelines on Perioperative Cardiovascular Evaluation for Noncardiac Surgery). Developed in collaboration with the American Society of Echocardiography, American Society of Nuclear Cardiology, Heart Rhythm Society, Society of Cardiovascular Anesthesiologists, Society for Cardiovascular Angiography and Interventions, Society for Vascular Medicine and Biology, and Society for Vascular Surgery. J Am Coll Cardiol 2007;50(17):1707-32.

40. Longo WE, Virgo KS, Johnson FE, Oprian CA, Vernava AM, Wade TP, et al. Risk factors for morbidity and mortality after colectomy for colon cancer. Dis Colon Rectum 2000;43(1):83-91.

41. Khan MR, Bari H, Zafar SN, Raza SA. Impact of age on outcome after colorectal cancer surgery in the elderly - a developing country perspective. BMC Surg 2011;11:17.

42. Panis $Y$, Maggiori L, Caranhac G, Bretagnol F, Vicaut E. Mortality after colorectal cancer surgery: a French survey of more than 84,000 patients. Ann Surg 2011;254(5):738-43.

43. Kehlet H, Wilmore DW. Evidence-based surgical care and the evolution of fast-track surgery. Ann Surg 2008;248(2):189-98.
44. Basse L, Billesbolle P, Kehlet H. Early recovery after abdominal rectopexy with multimodal rehabilitation. Dis Colon Rectum 2002;45(2):195-9.

45. Kehlet H, Dahl JB. Anaesthesia, surgery, and challenges in postoperative recovery. Lancet 2003;362(9399):1921-8.

46. Kalavrouziotis D, Buth KJ, Cox JL, Baskett RJ. Should all patients be treated with an angiotensin-converting enzyme inhibitor after coronary artery bypass graft surgery? The impact of angiotensin-converting enzyme inhibitors, statins, and $\beta$-blockers after coronary artery bypass graft surgery. Am Heart J 2011;162(5):836-43.

47. Kertai MD, Boersma E, Westerhout CM, Klein J, van Urk H, Bax JJ, et al. Reprinted article "A combination of statins and beta-blockers is independently associated with a reduction in the incidence of perioperative mortality and nonfatal myocardial infarction in patients undergoing abdominal aortic aneurysm surgery". Eur J Vasc Endovasc Surg 2011;42 (Suppl 1):S96-104.

48. Kuhn EW, Liakopoulos OJ, Choi YH, Wahlers T. Current evidence for perioperative statins in cardiac surgery. Ann Thorac Surg 2011;92(1):372-9.

49. Khan A, Yeung D, Wyatt B, Rafai T, Byant J, Coates A, et al. Effects of statins on postoperative sepsis, systemic inflammatory response syndrome and mortality after colorectal surgery. Crit Care 2009;13(Suppl 4):P47.

50. Balkwill F, Mantovani A. Inflammation and cancer: back to Virchow? Lancet 2001;357(9255):539-45.

51. Kundu JK, Surh YJ. Inflammation: gearing the journey to cancer. Mutat Res 2008;659(1-2):15-30.

52. Wong VK, Malik HZ, Hamady ZZ, Al-Mukhtar A, Gomez $\mathrm{D}$, Prasad KR, et al. C-reactive protein as a predictor of prognosis following curative resection for colorectal liver metastases. Br J Cancer 2007;96(2):222-5.

53. Gunter MJ, Stolzenberg-Solomon R, Cross AJ, Leitzmann MF, Weinstein S, Wood RJ, et al. A prospective study of serum C-reactive protein and colorectal cancer risk in men. Cancer Res 2006;66(4):2483-7.

54. Ali OF, Growcott EJ, Butrous GS, Wharton J. Pleiotropic effects of statins in distal human pulmonary artery smooth muscle cells. Respir Res 2011;12:137.

55. Allin KH, Nordestgaard BG, Flyger H, Bojesen SE. Elevated pre-treatment levels of plasma C-reactive protein are associated with poor prognosis after breast cancer: a cohort study. Breast Cancer Res 2011;13(3):R55.

56. University NZ [texto na Internet]. Auckland: University of Auckland - Simvastatin in Colorectal Surgery (StatCol); [cited 2012 Jan 09]. Available from: http://clinicaltrials.gov/ ct2/show/NCT00994903

\section{Correspondence to:}

Júlio César M. Santos Jr.

Avenida Ministro Urbano Marcondes, 516

12515-230 - Guaratinguetá (SP), Brazil

E-mail: instmed@provale.com.br 